\title{
IAMJ
}

INTERNATIONAL

AYURVEDIC

MEDICAL JOURNAL

\section{A CLINICAL STUDY TO EVALUATE THE EFFICACY OF BILVA TAILA ANUVASAN BASTI IN VATAJA PRAVAHIKA}

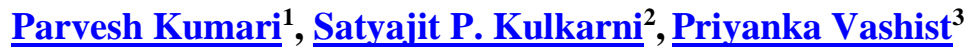

${ }^{1}$ Assistant Professor, Department of Panchakarma, National College of Ayurveda, Barwala-125121, Haryana, India

${ }^{2}$ Associate Professor \& HOD, Department of Panchakarma, Yashwant Ayurvedic College, Kodoli, Kolhapur, Maharashtra

${ }^{3}$ Assistant Professor, Department of Swasthvritta, Gaur Brahman Ayurvedic College Brahmanwas, Rohtak, Haryana, India

Corresponding Author: dr.parveshsheoran@gmail.com

https://doi.org/10.46607/iamj0909072021

(Published Online: July 2021)

Open Access

(C) International Ayurvedic Medical Journal, India 2021

Article Received: 25/06//2021 - Peer Reviewed: 10/07/2021 - Accepted for Publication: 11/07/2021

\section{Check for updates}

\section{ABSTRACT}

In the $21^{\text {st }}$ century due to sedentary lifestyle, irregular food habits like in taking of unwholesome food Virudhha quantity, quality and timings, one is always under tremendous mental stress this leads to gastric upset (Agniman$d y a$ ) which is said to be the root cause of various diseases like Grahani, Atisara and Pravahika. Pravahika is a disease characterized by straining in the process of passage of stool which is mainly by vitiated Vayu hence Vataja Pravahika is selected for our study and has a correlation with signs and symptoms of Amoebiasis which is a type of Dysentery. Aim: To evaluate the efficacy of Bilva Taila Anuvasan Basti and also to compare the efficacy of Bilva Taila Anuvasan Basti and Laghu Gangadhar Choorna in the management of Vataja Pravahika. Materials and Methods: It was an open randomized trial study, and the current study was planned for 60 patients of Vataja Pravahika. Thirty patients (Group A) were treated with Anuvasan Basti along with Laghu Gangadhar Choorna and in other Thirty (Group B) were treated with Laghu Gangadhar Choorna only. Results and Conclusion: Individually both groups have given relief in cardinal signs and symptoms of Vataja Pravahika. While 
comparing, it was statistically proved that Bilva Taila Anuvasan Basti (Group A) is more effective than Laghu Gangadhar Choorna (Group B) which shows the role /importance of Anuvasan Basti in the management of Vataja Pravahika.

Keywords: Vataja Pravahika, Amoebiasis, Bilva Taila Anuvasan Basti, Laghu Gangadhar Choorna

\section{INTRODUCTION}

Today's sedentary and busy lifestyle people do not have enough time to pay attention to their food and habits, one is always under tremendous stress which leads to gastric upset (Agnimandya) "Rogasarvepimandagni” Malfunction of Agni i.e., Mandagni causes improper digestion which leads to Pravahika. Psychological causes like fear etc., consumption of contaminated water and excessive consumption of alcoholic beverages and allergic foods also play a major role. It affects mainly those people who belong to such families, society or places where dietary habits and personal hygiene and sanitation are poor, and it has resemblance with Amoebiasis ${ }^{1}$ a type of Dysentery which is found quite widespread in a society where the hygiene conditions and the lack of effective sewage treatment plants encourage the spread of Amoeba. Amoebiasis affects about $15-20 \%$ of the Indian population ${ }^{2}$. The incidence of dysentery is greatest in the monsoon period and lowest during the driest part of the year. In Ayurveda, Pravahika is given as Vata Kaphaj Vyadhi. Acharya Susruta ${ }^{3}$ and Madhavkar ${ }^{4}$ have 1st identified Pravahika as a distinctive disease and Charaka ${ }^{5}$ as a symptom in Kaphaj Atisara. Kaviraj Gananath Sen ${ }^{6}$ has lucidly clarified that the word Pravahana means Kunthan 'Pravahananama Kunthana' which means 'Pravahi$k a$ ' the disease coined after the word Pravahana or Kunthan which is defined as the sound made by a person when to strain down to pass the stools in a small amount with a large quantity of Kapha and mucous or pus of blood with pain. Pravahika divided into four types ${ }^{7}$ namely Vataja, Pittaja, Kaphaja \& Raktaja in which we have taken Vataja Pravahika for our study. Vataja Pravahika ${ }^{8}$ is caused mainly by vitiated Vayu \& this vitiated Vayu tries to excrete the Kapha which is accumulated due to intake of Ahita Ahara in the Kostha of the patient. The accumulated
Kapha along with painful sticky Mal with foam come out by pressing force from the anus in the small quantity. Hence Vata is the main factor so one must treat the Vata Sthana first and Basti is the treatment that is applied directly to the main seat of Vata. As Acharya Susruta says Vata gets pacified in the same order as the unctuous enema is given which in turn leads to subsidence of Pravahika. Hence, we should pacify Vata in the case of Pravahika ${ }^{9}$. As Pravahika is a Vata Kapha Pradhan Vikara, Bilva Taila which is mentioned in Ashtang Hrudaya ${ }^{10}$ having the qualities of Vata Kaphahara, Agnideepak, Sangrahi and Stambhak were taken to evaluate the efficacy in this study. Hence the present study is designed to observe the role of Bilva Taila Anuvasan Basti which may be a safe and effective treatment in the management of Vataja Pravahika.

\section{AIM \& OBJECTIVE}

1. The present study aims to evaluate the efficacy of Bilva Taila Anuvasan Basti in Vataja Pravahika.

2. To compare the efficacy of Bilva Taila Anuvasan Basti and Laghu Gangadhar Choorna in the management of Vataja Pravahika.

\section{MATERIALS AND METHODS}

The study was a Randomized open trial study cleared by the institutional ethics committee on 21/03/2016 vide letter no. PGYACK/784/2016.60 patients were registered for this clinical study that completed the trial. The subjects suffering from Pravahika fulfilling the criteria of selection of the present study were selected for the trial. The subjects were subjected to detailed clinical examination and investigation as per the specially designed Performa. The present clinical study contains a sample size of 60 subjects. They were divided into two groups as group $\mathrm{A}$ and group B, each having 30 subjects. Group A subjects were subjected to Bilva Taila Anuvasan Basti and Shaman 
Ousadhi as Laghu Gangadhar Choorna and group B subjects were treated only by Shaman Ousadhi as Laghu Gangadhar Choorna for 12 days and follow up on the $13^{\text {th }}$ day.

\section{METHOD OF DETERMINATION OF SAMPLE} SIZE

$n=\frac{z^{2} p(1-p)}{d^{2}}$

Were,

$\mathrm{n}=$ sample size, $\mathrm{z}=$ standard deviation, $\mathrm{p}=$ prevalence rate $=4.0 \%=0.04, \mathrm{~d}=$ precision $=5 \%=0.05$ Substituting the values in the above formula.

$$
n=\frac{(1.96)^{2}(0.04)(1-0.04)}{(0.05)^{2}} n=58.98
$$$$
\boldsymbol{n}=\mathbf{5 9}
$$

So, a total 60 no. of patients will be selected for the study.

\section{Source of data}

Subjects attending the OPD and IPD of Panchakarma Department, Yashwant Ayurvedic College, Kodoli,
IPGTRC, Kolhapur, were selected and randomly categorized into 2 groups for study. Informed Consent from all the subjects was duly taken before started the interventions in each group.

\section{Criteria for selection of patients Inclusion Criteria}

Patients between the age group of 20 to 70 years, irrespective of gender and religion having cardinal signs and symptoms like Sapravahan Mala Pravriti, Muhur Muhur Mala Pravriti, Sakapha Mala Pravriti, Sashulam Mala Pravriti, Udar Shoola, No. of Mala Vega and Adhman were selected for the study.

\section{Exclusion Criteria}

1. Pt. below the age of 20 and above 70 yrs.

2. Patients having a medical, surgical illness that can complicate the Basti procedures.

3. Pregnancy and lactating mother.

4. Patient having Updravyas of Vataja Pravahika and Atisara and having signs \& symptoms of Pittaja, Kaphaja and Raktaja Pravahika.

\section{INVESTIGATIONS}

Stool examination- routine microscopic, Patients were checked for dehydration and weight change periodically.

\section{CRITERIA FOR ASSESSMENT-SUBJECTIVECRITERIA:}

Table 1: Sapravahana Mala Pravriti (Passage of stool with tenesmus)

\begin{tabular}{|l|l|l|}
\hline A & Nil/absent & 0 \\
\hline B & Mild & 1 \\
\hline C & Moderate & 2 \\
\hline D & Severe & 3 \\
\hline
\end{tabular}

Table 2: Muhur Muhur Mala Pravriti (Frequently Passage of Stool)

\begin{tabular}{|l|l|l|}
\hline A & Stool passes one or two times a day & 0 \\
\hline B & Passes stool 3-4 times & 1 \\
\hline C & Passes stool 5-6 times & 2 \\
\hline D & Passes stool more than six times & 3 \\
\hline
\end{tabular}

Table 3: Skapha Mala Pravriti - (Presence of Mucus In Stool)

\begin{tabular}{|l|l|l|}
\hline A & No visible mucus in stool. & 0 \\
\hline B & Visible mucus stickled to the stool. & 1 \\
\hline C & Passage of mucus with frequent stool & 2 \\
\hline D & Passage of a large amount of mucus in stool. & 3 \\
\hline
\end{tabular}


Table 4: Sashulam Mala Pravriti (Painful Defecation)

\begin{tabular}{|l|l|l|}
\hline A & No pain during Defecation & 0 \\
\hline B & Mild pain during Defecation & 1 \\
\hline C & Moderate pain during Defecation & 2 \\
\hline D & Severe pain during Defecation & 3 \\
\hline
\end{tabular}

Table 5: Pain in abdomen

\begin{tabular}{|l|l|l|}
\hline A & No abdominal pain & 0 \\
\hline B & Sometime/ rarely & 1 \\
\hline C & Intermittent cramps lower abdominal pain which is relieved by passage of flatus \& stool. & 2 \\
\hline D & Continuous abdominal pain & 3 \\
\hline
\end{tabular}

Table 6: Daurblaya- (Weakness, Fatigue)

\begin{tabular}{|l|l|l|}
\hline A & No fatigue & 0 \\
\hline B & Mild (Not affecting his daily activities) & 1 \\
\hline C & Moderate (affecting his daily activities) & 2 \\
\hline D & Severe (activities reduced due to weakness) & 3 \\
\hline
\end{tabular}

\section{B) OBJECTIVE-}

Table 7: Number (No.) of Mala Vega (Mala Vega Sankhya): Frequency of defecation is there, but here several Vega is count when Mala is passed.

\begin{tabular}{|l|l|}
\hline Once a day & 0 \\
\hline Twice a day & 1 \\
\hline Thrice a day & 2 \\
\hline More than thrice & 3 \\
\hline
\end{tabular}

Table 8: Adhaman (Flatulence)

\begin{tabular}{|l|l|}
\hline Absent & 0 \\
\hline Present & 1
\end{tabular}

\section{Source of Materials}

Raw materials for the present study of Bilva Taila and Dashmooladi Kwatha and Laghu Gangadhar Choorna were authentified and Standardized in S.G phytopharma, an Authentified ISO Pharmacy Kolhapur and prepared classically in the pharmacy of Rasa Shastra and Bhaishajya Kalpana, Yashwant Ayurvedic College PGT \&RC, Kodoli, Kolhapur.

\section{Intervention}

\section{Group A: Bilva Taila Anuvasan Basti} Preparation of BilvaTaila

Dried pulp of unripe fruit was collected $\&$ pulp was dried and oil was prepared by the following method.

1. Bilva Phal Majja fruit pulp - $1 \mathrm{~kg}$
2. Sesame oil - 4 lit

3. Go Mutra - 16 litre

This mixture was boiled until oil remains. There is a description of Sneh Pak Vidhi mentioned in Sharangdhar Samhita ${ }^{11}$. That was followed. Prepared oil was used for Anuvasan Basti.

\section{METHOD OF BASTI PREPARATION: -}

For Anuvasan Basti - For Basti preparation, warm oil was taken $\&$ administered by anorectal route as per Basti Vidhi mentioned in Ayurvedic texts ${ }^{12}$

For Niruh Basti- Dashmooladi Kwath - $700 \mathrm{ml}$, sesame oil-150 ml, rock salt - $10 \mathrm{gm}$, honey $-50 \mathrm{ml}$ \& Vacha Kalk - 40 gm taken \& Basti was prepared as per Basti Vidhi mentioned in Ayurvedic texts ${ }^{13}$ 
Total 12 Basti was given in which 9 Anuvasan \& $3 \quad$ administered.

Niruha was given as after 3 Anuvasan, 1 Niruha was

\section{DRUG ADMINISTRATION DETAILS}

Table 9: BILVA TAILA ANUVASAN BASTI-

\begin{tabular}{|l|l|}
\hline Anuvasan Basti & Bilva Taila \\
\hline Matra & For Anuvasan $-120 \mathrm{ml} /$ Basti, Niruha $-960 \mathrm{ml} /$ Basti \\
\hline Total no of Basti & 12 \\
\hline Temp & Koshna Taila \\
\hline Kala & 10 am to $2 \mathrm{pm}$ \\
\hline Duration & 12 days [continuous] \\
\hline No. of patients & 30 \\
\hline Follow up & $13^{\text {th }}$ day \\
\hline
\end{tabular}

\section{LAGHU GANGADHAR CHOORNA ${ }^{14}$}

It balances Vata \& Pitta and having the property of regulating the bowel habits along with Deepan, Pachan \& Ropan Gunas which helps in expelling intestinal gases, prevents fermentation \& activates digestion \& thus improves appetite. Prepare Choorna with the below drugs in equal parts and administered internally with $G u d a^{15}$.

Table 10:

\begin{tabular}{|l|l|}
\hline Musta & 1 part \\
\hline Indrayava & 1 part \\
\hline Bilva & 1 part \\
\hline Lodhra & 1 part \\
\hline Mochrasa & 1 part \\
\hline Dhatki & 1 part \\
\hline
\end{tabular}

Preparation of Laghu Gangadhar Choorna

For the preparation of Choorna, the drugs mentioned was cleaned and dried properly. They were finely powdered and well mixed. The powder is fine with at least 80 mesh sieves. It should not adhere together or moist.

Table 11

\begin{tabular}{|l|l|}
\hline NAME OF DRUG & LAGHU GANGADHAR CHOORNA \\
\hline Dose & $3 \mathrm{gm}$ \\
\hline Anupan & Jaggery $-5 \mathrm{gm}$ \\
\hline Duration & 2 times a day after meal for 12 days \\
\hline
\end{tabular}

Symptom wise relief after treatment in both groups

As grading used assessment parameters were ordinal, "Wilcoxon Signed Rank test" is used for intra-group comparisons (i.e. before and after treatment of a group) while for intergroup comparisons, (i.e. for comparing two groups with each other) "Mann-
Whitney $U$ test is used. For the Nominal Scale, Mc Nemar's test is applied to test the efficacy of both the groups at a $5 \%$ level of significance.

We have a test hypothesis for each parameter and the result is interpreted accordingly. The level of significance is kept at 0.05 . 


\section{OBSERVATIONS AND RESULTS}

Table 12: Group A

\begin{tabular}{|l|l|l|l|l|l|l|}
\hline Parametric & BT & AT & Wilcoxon Signed & P-value & $\%$ Effect & Result \\
\hline Sapravahan Mala Pravriti & 2 & 0 & $-4.995^{\mathrm{a}}$ & 0.000 & $93.4 \%$ & Significant \\
\hline Muhur-Muhur Mala Pravriti & 2 & 0 & $-5.002^{\mathrm{a}}$ & 0.000 & $79.1 \%$ & Significant \\
\hline Sakapha Mala Pravriti & 2 & 0 & $-4.963^{\mathrm{a}}$ & 0.000 & $70.2 \%$ & Significant \\
\hline Sashulam Mala Pravriti & 2 & 0 & $-4.977^{\mathrm{a}}$ & 0.000 & $94.5 \%$ & Significant \\
\hline Udarshoola & 1 & 0 & $-4.756^{\mathrm{a}}$ & 0.000 & $89.7 \%$ & Significant \\
\hline Daurbalya & 2 & 1 & $-4.944^{\mathrm{a}}$ & 0.000 & $68.5 \%$ & Significant \\
\hline Malavega & 2 & 1 & $-4.916^{\mathrm{a}}$ & 0.000 & $73.4 \%$ & Significant \\
\hline
\end{tabular}

Group A showed a 93.4\% relief in Sapravahan Mala Pravrutti, which was statistically highly significant $(\mathrm{p}<0.001)$ at a $5 \%$ level of significance. Group A showed a $79.1 \%$ relief in Muhur Muhur Mala Pravriti, which was statistically highly significant $(\mathrm{p}<0.001)$ at a $5 \%$ level of significance. Group A showed $70.2 \%$ relief in Sakapha Mala Pravriti, which was statistically highly significant $(\mathrm{p}<0.001)$ at a 5\% level of significance. Group A showed a $94.5 \%$ relief in Sashulam Mala Pravriti, which was statisti- cally highly significant $(\mathrm{p}<0.001)$ at a $5 \%$ level of significance. Group A showed an $89.7 \%$ relief in Udarshoola, which was statistically highly significant $(\mathrm{p}<0.001)$ at a $5 \%$ level of significance. Group A showed a $68.5 \%$ relief in Daurbalya, which was statistically highly significant $(\mathrm{p}<0.001)$ at a $5 \%$ level of significance. Group A showed a $73.4 \%$ relief in $\mathrm{Ma}$ lavega, which was statistically highly significant $(\mathrm{p}<0.001)$ at a $5 \%$ level of significance.

\section{Table 13:}

\begin{tabular}{|l|l|l|}
\hline Non-Parametric & Group A & AT \\
\hline Adhaman & BT & $16(53.3 \%)$ \\
\hline Absent & $0(0 \%)$ & $14(46.7 \%)$ \\
\hline Present & $30(100 \%)$ &
\end{tabular}

Group A showed a 53.3\% relief in Adhaman, which was statistically highly significant $(\mathrm{p}<0.001)$ at a $5 \%$ level of significance.

Table 14: Group B

\begin{tabular}{|l|l|l|l|l|l|l|}
\hline Symptoms & B T & AT & Wilcoxon Signed & P-value & $\%$ Effect & Result \\
\hline Sapravahan Mala Pravriti & 2 & 0 & $-4.964^{\mathrm{a}}$ & 0.000 & $46.6 \%$ & Significant \\
\hline Muhur-Muhur Mala Pravriti & 2.5 & 1 & $-4.939^{\mathrm{a}}$ & 0.000 & $52.7 \%$ & Significant \\
\hline Sakapha Mala Pravriti & 2 & 1 & $-5.035^{\mathrm{a}}$ & 0.000 & $49.4 \%$ & Significant \\
\hline Sashulam Mala Pravriti & 2 & 1 & $-5.203^{\mathrm{a}}$ & 0.000 & $45.4 \%$ & Significant \\
\hline Udar Shoola & 1 & 0 & $-4.914^{\mathrm{a}}$ & 0.000 & $45.0 \%$ & Significant \\
\hline Daurbalya & 2 & 1 & $-5.324^{\mathrm{a}}$ & 0.000 & $47.8 \%$ & Significant \\
\hline Malavega & 2 & 1 & $-5.035^{\mathrm{a}}$ & 0.000 & $44.3 \%$ & Significant \\
\hline
\end{tabular}


Group B showed a 46.6\% relief in Sapravahan Mala Pravrutti, which was statistically highly significant $(\mathrm{p}<0.001)$ at a $5 \%$ level of significance. Group B showed a 52.7\% relief in Muhur - Muhur Mala Pravriti, which was statistically highly significant $(\mathrm{p}<0.001)$ at a $5 \%$ level of significance. Group B showed 49.4\% relief in Sakapha Mala Pravriti, which was statistically highly significant $(\mathrm{p}<0.001)$ at a 5\% level of significance. Group B showed a $45.4 \%$ relief in Sashulam Mala Pravriti, which was statisti- cally highly significant $(\mathrm{p}<0.001)$ at a $5 \%$ level of significance. Group B showed a $45.0 \%$ relief in Udarshoola, which was statistically highly significant $(\mathrm{p}<0.001)$ at a $5 \%$ level of significance. Group B showed a $47.8 \%$ relief in Daurbalya, which was statistically highly significant $(\mathrm{p}<0.001)$ at a $5 \%$ level of significance. Group B showed a $44.3 \%$ relief in $\mathrm{Ma}$ lavega, which was statistically highly significant $(p<0.001)$ at a $5 \%$ level of significance.

Table 15

\begin{tabular}{|l|l|l|}
\hline Non-Parametric & Group B & \\
\hline Adhaman & BT & AT \\
\hline Absent & $0(0 \%)$ & $3(10 \%)$ \\
\hline Present & $30(100 \%)$ & $27(90 \%)$ \\
\hline
\end{tabular}

Group B showed a 10\% relief in Adhaman, which was statistically insignificant $(\mathrm{p}<0.001)$ at a $5 \%$ level of significance.

Table 16: Comparative Analysis

\begin{tabular}{|l|l|l|l|}
\hline Parameter & Group A & Group B & Comparative efficacy \\
\hline Sapravahan Mala Pravriti & Significant & Significant & Group A \\
\hline Muhur-muhur Mala Pravriti & Significant & Significant & Group A \\
\hline Sakapha Mala Pravriti & Significant & Significant & Group A \\
\hline Sashulam Mala Pravriti & Significant & Significant & Group A \\
\hline Udarshoola & Significant & Significant & Group A \\
\hline Daurbalya & Significant & Significant & Group A \\
\hline No. of Malavega & Significant & Significant & Group A \\
\hline Adhaman & Significant & Insignificant & Group A \\
\hline
\end{tabular}

Table 17

\begin{tabular}{|l|l|l|}
\hline Parameter & Group A & Group B \\
\hline Sapravahan Mala Pravriti & $93.4 \%$ & $46.4 \%$ \\
\hline Muhur-Muhur Mala Pravriti & $79.1 \%$ & $52.7 \%$ \\
\hline Sakapha Mala Pravriti & $70.2 \%$ & $49.4 \%$ \\
\hline Sashulam Mala Pravriti & $94.5 \%$ & $45.4 \%$ \\
\hline Udarshoola & $89.7 \%$ & $45.0 \%$ \\
\hline Daurbalya & $68.5 \%$ & $47.8 \%$ \\
\hline No.of Malavega & $73.4 \%$ & $44.3 \%$ \\
\hline Adhaman & $53.3 \%$ & $10 \%$ \\
\hline Average \% efficacy & $\mathbf{7 8 \%}$ & $\mathbf{4 3 \%}$ \\
\hline
\end{tabular}




\section{The overall effect of therapy}

Table 18: Distribution of patients according to relief:

\begin{tabular}{|l|l|l|l|l|}
\hline \multirow{2}{*}{ Overall Effect } & Group A & \multicolumn{2}{l|}{ Group B } \\
\cline { 2 - 5 } & Frequency & Percentage & Frequency & Percentage \\
\hline No Improvement & 0 & 0.0 & 0 & 0.0 \\
\hline Mild Improvement & 0 & 0.0 & 13 & 43.3 \\
\hline Moderate Improvement & 2 & 6.7 & 17 & 56.7 \\
\hline Marked Improvement & 28 & 93.3 & 0 & 0.0 \\
\hline TOTAL & 30 & 100.0 & 30 & 100.0 \\
\hline
\end{tabular}

In Group A, out of 30 patients, 28 patients (93\%) showed marked improvement while 2 patients $(7 \%)$ showed moderate improvement., In Group B, 17 pa- tients $(56.7 \%)$ were observed to show moderate improvement while 13 patients (43\%) showed mild improvement.

Graph 1 - Overall effect of therapy

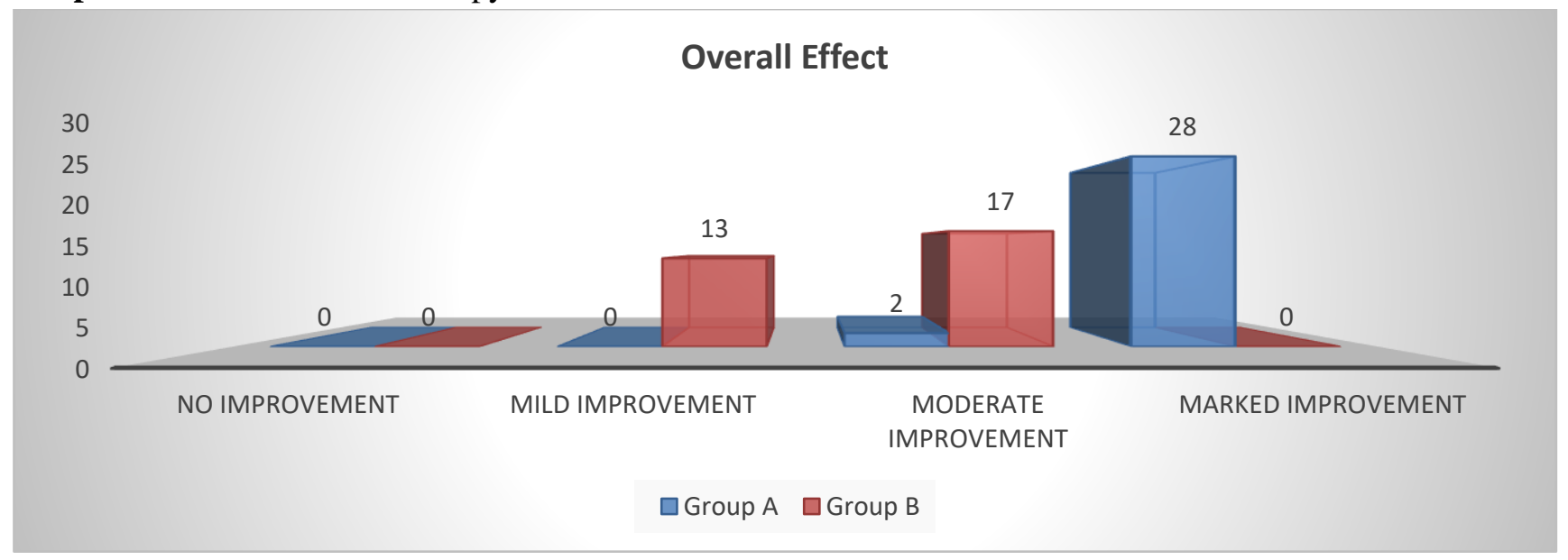

\section{DISCUSSION}

Varieties of modalities have been explained in Ayurvedic texts for management of Pravahika for Vataja Pravahika, where Vata is predominant and pain is the present use of Bilva, Guda, Taila is mentioned. It is clear from the conceptual study Vata is the main factor and Basti has been glorified as the definitive therapy to subtle the vitiated Vata and Vata Pradhan Vyadhi (A.S.Su.28/12). Basti therapy is mentioned by many Acharayas in Pravahika, if there is Kshina Mala (small quantity of faeces) and Dosha have given up their normal seats, where Vata is present one should use Anuvasan Basti. For Anuvasana Basti, Bilva Taila was used recommended by Acharaya Vagbhatt in Atisara Chikitsa. A total of 60 subjects were studied in two groups with 30 in each group i.e., Group A Bilva Taila Anuvasan Basti with Laghu Gangadhar Choorna and Group B only Laghu Gangadhar Chorna were administered. Subjects attending the OPD and IPD of the Department of Panchakarma, Yashwant Ayurvedic College, Kodoli were taken randomly for this study. Special clinical performa based on criteria and selection and parameters for assessment of subject was prepared. Based on the physicochemical properties of Bilva Taila, probable Samprapti Vighatana can be understood. In this disease, Vata and kapha are the main culprits. Its main action against Vata and Kapha by its Virya that is Ushna. It also exhibits Vatkaphashamak Prabhav which destroys the Vata and Kapha. From the Samprapti of Vataja Pravahika, the main Dushya involved is Rasa Dhatu and Purisha. It 
has Tikta and Kashaya Rasa which improves digestion and made first Dhatu and last Purisha in proper form. And, it has Deepan and Pachan Karma which also improves Agni. The disease mainly exhibits Atipravritti type of Sroto Dushti and mainly Annavaha and Purishvaha Stroto Dushti occur by its Deepan, Pachan and Grahi property it decreases Strotagata Ama and Picchilita and relieves Atipravritti. By Ushna Virya, Bilva acts on Uplepa and clean the Strotas. Bilva is Kashaya, Tikta and Ushna in Virya. So, it enhances the function of Samana Vayu. Thus, it is Deepan and Pachan in nature. Bilva by its Ushna, Tikshna virtues acts as Grahi ${ }^{16}$. Sangrahi property of Bilva is very useful to treat the increased frequency of defecation and consistency of stool. However, it first makes proper digestion of the Apakwa Mala. Thus, it enhances the Agni. Its Deepan and Pachan property improve the function of Agni. Pakwashaya is the adhisthana of Vataja pravahika. As Bilva contains Marmelosin, Mucilage,Musin these helps in re build the mucosa by the inflammatory changes in the large intestine. Marmelosin kills the protozoa and antibacterial in nature. An Ama means unripe and undigested Anna Rasa. It needs proper Paka by the virtue of Ushna Virya, Deepan and Pachan property, Ama Pachan will take place. This Ama Pachan causes Stroto Mukha Visodhana. Pharmacological activities like Antidiarrhoeal, Anti dysentery, Anti-bacterial, Antispasmodic, Anti-inflammatory, carminatives etc. check the post infections. As it contains Tila Taila ${ }^{17}$ also which is Guru, Snigdha and Madhura and is best among all Dravyas for Vata Shaman and will decrease the Sapravahan, Sashoolam and Udarshoola symptoms markedly. It will Balya for Pakwashaya also. Beside this Gomutra ${ }^{18}$ having Katu, Tikshna and Ushna properties was also used in the preparation of Taila which purifies and clears all blocks in body channels. Thus, in a nutshell Bilva Taila because of its Sangrahi, Agni Deepak, Aam Pachak, Stambhak and Rasayan helps to disintegrate the pathogenesis of Vataja Pravahika and hence diminished the cardinal signs and symptoms of Vataja Pravahika. It is clear from the conceptual study that vitiated Vata is the main factor in the Samprapti of Vataja Pravahika and Bas$t i$ enters the colon, which is the main seat of Vata Dosha and by its potency, active principles destroy Vata Dosha, which is the originator of all the disease. Bilva Taila Anuvasan Basti is mentioned by Acharaya Vagbhatt as it is a Annavaha Strotas Vyad$h i$ and malfunction of Agni is there so digestion is not proper and drug administration by enemas avoids having the medication pass through the entire gastrointestinal tract, therefore simplifying the delivery of the medication to the affected area and limiting the amount that is absorbed into the bloodstream. In Samprapti of Vataja Pravahika, Dosha changes its seat. The Kapha which is situated in Amashaya normally is bought in the Guda by vitiated Vayu (Vata). So, we must treat the Vata Sthana first for which Basti is the best choice. Bilva, is selected for Anuvasana Basti as It is Vata Kapha Nashak in nature. Bilva is Ushna and Tikshna in property, which destroys Kapha and Vata tries to bring the function of Agni to a normal level. This is best obtained by repeated use of Anuvasana Basti. Normally, one should use Niruha Basti after 3 Anuvasana, only one type of Basti should not be used continuously. If Anuvasan is given continuously it aggravates biohumors and reduces the digestive fire; So, Dashmooladi Niruha Basti was used after 3 Bilva Taila Anuvasan Basti to restore the normalcy and pacify the disease. Dashmoola has Tridoshghana, Deepan, Anuloman, Amapachak properties and have Shothaghana and Shoolaghana action also. It not only pacifies Vata but also alleviates Kapha and relieves pain which is the main symptom of Vataja Pravahika. In Group A, Bilva Taila Anuvasan Basti was given for 12 days; in which 9 Anuvasan and 3 Niruha were given as after 3 Anuvasan, 1 Niruha was given which was followed by administration of Laghu Gangadhar Choorna 3 gms for 12 days. In Group B, only Laghu Gangadhar Choorna 3gms for 12 days was given to the patients. In Vataja Pravahika, mainly there is vitiation of Vata, Kapha and Agni usually Mandagni is seen. This ultimately results in Ama formation. Laghu Gangadhar Choorna has properties like Katu, Tikta Rasa and Katu Vipak. Laghu, Ruksha, Tikshna, 
Snigdha Guna acts as Agni Deepak and Amapachak. Tikta Rasa and Laghu, Ruksha Guna helps in reducing the colonic motility and thereby helps in Sama Mala Pravriti. It was observed that both Group A and Group B showed significant results in subjects of Pravahika. But in overall assessment in both subjective and objective parameters, it was observed that in Group A, the percentage of relief was $78 \%$ and in Group B it was only $43 \%$. And, in the total effect of therapy in 60 subjects of Pravahika in Group A $93.3 \%$ of subjects got marked improvement, while in group B it was $0 \%$ or nil. The total effect of therapy in 60 subjects of Pravahika in Group A 7\% of subjects got moderate improvement while in Group B it was $56.7 \%$ and $43.3 \%$ of subjects got mild improvement.

After a keen observation of results, it can be concluded that Group A is more effective than Group B in the management of Vataja Pravahika.

\section{CONCLUSION}

The following conclusion can be drawn based on literature and observation made in this study. Vataja Pravahika is one of the commonest diseases of Annvaha and Purishvaha Strotas (Gastro-intestinal tract). It is Ashukari Vyadhi (Acute) producing weakness and Rasa Kshaya if not treated within proper time. In modern parlance, it is closely related to the Amoebicdysentry. In Vataja Pravahika, Vata gets provoked due to the intake of Ruksha Ahara and other provocative measures. Vata Dosha is the main culprit especially Samana and Apana Vayu and Kapha are the Anubandhi Dosha. Observations supported this clinically as the majority of patients were of Vata Kaphaj Prakruti. Observations show a close resemblance to epidemiology of disease in terms of age (50-60) yr. the age group is the Parihani Kala (Sh. Pu.6/19) and Dhatu Kshaya occurs which leads toVata Prakopa and leads Vanaja Pravahika. Basti is considered the best line of treatment for Vata Vyadhis. One Yoga described in Ashtang Hridya in the form of Taila was selected for Basti therapy (Bilva Taila Anuvasan) and Shaman therapy for the Laghu Gangadhar Choorna for the treatment of
Vataja Pravahika. This formulation has proved to be very effective in the form of Basti in Vataja Pravahika. Basti is proved as Moolagami Chikitsa, as it first goes into Pakwashaya which is the Moola Sthana of Vata and Adhisthan of Vataja Pravahika and does it Sarvadaihika Karma by its Virya and expelled the vitiated Dosha. One more enthusiastic aspect of Ayurvedic management regarding my article that I didn't find any hazardous effects during the treatment which is a great benefit to the patients rather than modern science. Comparisons of overall effect observed in patients of both the groups showed that Group A Basti Poorvak Shaman therapy offered better results. Then Group B i.e., only Shaman therapy also showed a good effect on Vataja Pravahika but Group A Bilva Taila Anuvasan Basti proved better statistically and symptomatologically. The present study showed highly significant results, but the study was carried out on a smaller no of patients and should be carried out for a longer duration. From the above study, it has been concluded that Bilva Taila Anuvasan Basti is efficacious for relieving the signs and symptoms of Vataja Pravahika.

\section{REFERENCES}

1. http://www.nhp.gov.in/disease/digestive/amoebiasis

2. K. Park, Park's Textbook of Preventive and Social medicine, M/S Banarsidas BHANOT Publishers Jaipur, reprint 2015, Epidemiology of Communicable Disease, Ch.5, pg. no. 241.

3. Kaviraj Ambika Dutt Shastri, Susruta Samhita, Choukhamba Sanskrit Publication Varanasi, reprint 2010, Uttar tantra, Atisarchikitsa, ch. 40, verse no. 139, pg. no. 295.

4. Shree Yadunandan Upadhyaya, Madhav Nidana, Choukhamba Prakash Varanasi, reprint 2015, Atisarnidanam, Ch.13, verse no. 21, pg no. 175.

5. Ravidutt Tripathi, Charak Samhita, Choukhamba Prakash Varanasi, Reprint 2010, Chikitsa Sthana Atisarchikitsa, ch. 19, verse no. 7, pg no. 467.

6. Kaviraj Ambika Dutt Shastri, Susruta Samhita, Choukhamba Sanskrit Publication Varanasi, reprint 2010, Uttar tantra, Atisarchikitsa, ch. 40, verse no. 140, pg. no. 296. 
7. Ravidutt Tripathi, Charak Samhita, Choukhamba Prakash Varanasi, Reprint 2010, Chikitsa sthana Atisar chikitsa, ch. 19, verse no. 30, pg no. 473.

8. Kaviraj Ambika Dutt Shastri, Susruta Samhita, Choukhamba Sanskrit Publication Varanasi, reprint 2010, Uttar tantra, Atisar chikitsa, ch. 40, verse no. 152, 153, pg. no. 300 .

9. Bhramanand Tripathi, Ashtanga Hridyam, Choukhamba Prakashan Varanasi, reprint 2017, Chikitsasthana, Atisarchikitsa, Ch. 9, verse no. 118, 119, pg no. 693.

10. Bhramanand Tripathi, Shrangdhar Samhita, Choukhamba Surbharti Publication, Varanasi, reprint 2017, Madhyam Khanda, Tailaprakaran, ch. 9, verse no. 1-3, pg no. 144.

11. Bhramanand Tripathi, Shrangdhar Samhita, Choukhamba Surbharti Publication, Varanasi, reprint 2017, Uttar Khanda, Anuvasan Basti, Ch. 5, verse no. 23-26, pg no 232.

12. Bhramanand Tripathi, Shrangdhar Samhita, Choukhamba Surbharti Publication, Varanasi, reprint 2017, Uttar Khanda, Niruha Basti, Ch. 6, verse no.8-10, pg no 237, 238.

13. Bhramanand Tripathi, Shrangdhar Samhita, Choukhamba Surbharti Publication, Varanasi, reprint 2017, Madhyam Khanda, Choornaprakaran, ch. 6, verse no. 48-49, pg no. 121.

14. K. Nishteswar \& R. Vaidyanath, Sahasra Yoga, Choukhamba Krishnadas Academy, Varanasi, reprint 2008, Choorna Prakaran, ch. 4, pg no. 162.

15. Bhramanand Tripathi, Shrangdhar Samhita, Choukhamba Surbharti Publication, Varanasi, reprint 2017, Madhyam Khanda, Choornaprakaran, ch. 6, verse no. 1-2, pg no. 116.

16. Acharaya Priyavrat Sharma, Dravyaguna Vigyan -2, Choukhambha Bharti Academy, reprint 2006, pg 456.

17. Kaviraj Ambika Dutt Shastri, Susruta Samhita, Choukhamba Sanskrit Publication Varanasi, reprint 2018, Sutrasthana, Dravdravya vidhi, Tailavarga, Ch. 45, verse no.112, pg no. 230.

18. Kaviraj Ambika Dutt Shastri, Susruta Samhita, Choukhamba Sanskrit Publication Varanasi, reprint 2018, Sutrasthana, Dravdravya vidhi, Mutravarga, Ch. 45, verse no. 220, pg no 240.

\section{Source of Support: Nil Conflict of Interest: None Declared}

How to cite this URL: Priyanka Vashist et al: A Clinical Study To Evaluate The Efficacy Of Bilva Taila Anuvasan Basti In Vataja Pravahika. International Ayurvedic Medical Journal \{online\} 2021 \{cited July 2021\} Available from: http://www.iamj.in/posts/images/upload/1372_1382.pdf 